\title{
Key Role of Millennial Generation in Rural Agricultural Development In Indonesia: Cohort Generation Theory Approach
}

\author{
Gontom Citoro Kifli ${ }^{1,}{ }^{\text {, }}$, Slameto Slameto ${ }^{2}$, Juliana Carolina Kilmanun ${ }^{1}$, Dadan Permana ${ }^{1}$, \\ Melia Puspitasari ${ }^{1}$, Ester Justina Simanjuntak ${ }^{1}$, Chetty Meitrianty ${ }^{3}$ \\ ${ }^{1}$ Assessment Institute for Agricultural Technology of West Kalimantan, 78241 Pontianak, Indonesia \\ ${ }^{2}$ Assessment Institute for Agricultural Technology of Lampung, 35145 Lampung, Indonesia \\ ${ }^{3}$ Indonesian Center for Agricultural Training of Lembang, 40791 West Bandung, Indonesia
}

\begin{abstract}
Agricultural development actors in Indonesia are currently dominated by elderly farmers and a small proportion of young farmers. Another condition is that the farming system in Indonesia is generally subsistence. Several good potentials in the context of agricultural development in Indonesia today, firstly, the productive working age group is dominated by youth, especially the millennial generation, and secondly, the growing rapidly used internet networks. The condition of subsistence farming and the lack of young actors in agriculture, but on the other hand there is the potential of the millennial generation and availability of internet networks access. This study employed a quantitative research method. The purpose of this research is to see the current condition of agricultural development in Indonesia concerning its current potential. Another objective is to design the appropriate strategy for exploiting this potential to accelerate agricultural development in Indonesia. The results obtained from this research are the high level of accessibility of rural communities as initial capital for agricultural development in Indonesia for now. The millennial generation who dominates the working age in Indonesia can maximize their role in the agricultural sector in rural areas through developing entrepreneurship based on the use of internet networks.
\end{abstract}

\section{Introduction}

The agricultural sector in Indonesia is still a sector that contributes positively to the economy in Indonesia now. This condition can be seen from the Statistics Indonesia data showing that the GDP from the agricultural sector provides a high contribution to the national GDP so that the agricultural sector is still a mainstay for the Indonesian national economy. However, the conditions are different from the level of welfare of farmers generally, as the main actors or producers of agricultural commodities. [1] showed that the Farmers Terms of Trade (FTT) in January 2021 was recorded at 103.26. FTT is calculated from the ratio between the price received by farmers (PR) to the price paid by farmers (PP),

* Corresponding author: keevle354@gmail.com 
if the rate of increase in PR is higher than the rate of PP then the FTT will increase, and vice versa. The FTT movement identifies movements in the level of welfare of farmers. FTT more than 100 means that the farmers experience a surplus or economic benefits of their farming [2]. FTT is an indicator commonly used in Indonesia in looking at the welfare of farmers, although according to [3] there are several weaknesses of the FTT assessment, such as its direct relationship with welfare and the influence of the use of technological innovation.

The current condition of agriculture in Indonesia is generally still subsistence, which is characterized by a farmer's goal of his farming is only to meet the needs of his life and that of his family [4-8]. [8] stated that in Moldova, subsistence agriculture is still not oriented towards the commercialization of its production. The result of research by [9] in East Europe indicates that the poorest households from the largest cluster. They possess low natural, physical, and social capital, operating small-scale and undercapitalised farms with little nonagricultural income. However, [10] revealed that under some conditions, subsistence can play a stabilising role and have positive impacts on total agriculture in Central and Eastern Europe. This condition is like happening in Nigeria, where research results stated by [11] that subsistence agriculture contributes not just to the agricultural development of rural communities, but Nigeria as a whole. [12] expressed that Farmers' knowledge, as well as access to credit, technology adoption, marketplace, and traders, played significant roles in improving rural welfare or to helping subsistance farmers. One of the obstacles in national agricultural development in Indonesia is the limited number of main actors in agriculture, namely farmers. Some of the farmers are now elderly. Census data of Indonesia Agriculture at 2013 showed that proportion of farmers over the age of 40 until 54 years old is the largest years group, namely $41 \%$. The second largest proportion is the age group of more than 55 years old which can be classified as old farmers, namely $27 \%$, while the younger generation group with the age of less than 35 years old is only $11 \%$. [13], so that it can directly affect the work productivity of these farmers, so it is necessary to have a regeneration of farmer labour that can replace old farmers by the younger generation who are involved in agriculture. Currently, Indonesia is experiencing a demographic dividend, so that this condition is a valuable asset in Indonesia's national development in general for now and for the next few years, especially in the agricultural sector.

The demographic dividend occurs during a demographic transition marked by a two-fold increase in the number of working people (15-64 years old), accompanied by a delay in the growth of the young population (under 15 years old), and the fewer number of elderly people (over 64 years old) [14]. This demographic dividend phenomenon occurs as a result of the Birth Control Program which was implemented intensively several decades ago, between the 1980-1990s. In the language of population economics, the demographic dividend is interpreted as an economic benefit caused by the increasing amount of savings from the productive population. In this case, the demographic dividend in the first wave on the year 2010 to 2020 occurs in the productive population segment, $52.63 \%$, who cover 1 elderly per 100 population and 5 children under five per 100 population. The positive trend of demographic dividend will continue from the year 2020 to 2030.

The demographic dividend condition is in line with the current phenomenon, namely the birth and thrives of the millennial generation, also known as the $\mathrm{Y}$ generation. The millennial generation is one part of the group that fills the demographic dividend, even becomes a big part of it, because they were born in the 1980-1990s era. A person is included in the millennial generation if born between the year 1982-2000, after 1980 [15], 1980-2000 [16], 1977 to 1995 [17]. One of the characteristics of the millennial generation is that they know and master information technology well, or what is commonly referred to 
as digital literacy or digital natives. The millennial generation currently reaches $25.87 \%$ of Indonesia's population, or around 70 million people [1].

The millennial generation who are very close to the digital world and the internet, are synergized and supported by the current conditions of internet access in Indonesia. The results of a survey conducted [18] show that in 2019, internet penetration in Indonesia reached $73.7 \%$ of the Indonesian population or $196,714,070$ people. The daily internet connection through cell phones reaches $95.4 \%$. [1] noted that in the year 2019 as many as $63.53 \%$ of the Indonesian population had cell phones. The signal strength spread throughout Indonesia, as many as $69.33 \%$ had a strong signal, $23.55 \%$ had a weak signal and $7.11 \%$ had no cellular signal.

The condition that occurs between the still few young farmers or the young generation working in agriculture, but on the other hand, the very potential of the millennial generation as an effect of the demographic dividend and the rapid development of Information Technology is an interesting thing to research the importance of the role of generations millennials in contributing to agriculture in Indonesia. The purpose of this research is to analyze the condition of the millennial generation, then analyze the conditions of the millennial generation as the internet generation in their position and role in the agricultural sector in Indonesia, and to design a pattern for the role of the millennial generation in agriculture in Indonesia. The research was conducted using the cohort generation theory approach.

\section{Methodology}

This study employed a quantitative research method. The analysis used is descriptive statistical analysis. Research data were obtained from reliable sources, such as scientific journals, books, reports, legal official documents of government and private institutions, both at the regional and national levels in Indonesia. This study used a quantitative approach. Data were analyzed, processed, translated, and described descriptively.

\section{Results and Discussion}

The theory of group generation or cohort generation is defined as everyone who comes into being at the same historical moment, that is, everyone belonging to the same group [19-21]. On the other hand, cohort generation does not have a direct relationship with genealogy or lineage. It is defined, instead, as everyone who is "brought into being" at the same historical moment that is, everyone who belongs to the same cohort-group. All members of the same cohort generation live in the same social or historical time. At any given moment, members of a cohort generation can all be found in a common age bracket. The classification in the cohort generation theory comes from the United States, however, this theory can be used in conditions in Indonesia, because the conditions that arise or the birth of this generation occur globally, such as the birth of the baby boomers generation, namely at the end of The World War II, and the X generation. , which is happening worldwide, as well as generations $\mathrm{Y}, \mathrm{X}$, and $\mathrm{Z}$ which are marked by the birth and thrive of Information Technology, especially the internet, which occurred and spread throughout the world in a short time. These conditions make the cohort generation theory relevant when used for conditions in Indonesia.

Generation X and baby boomers who were born between the years 1960-1980 [16], when viewed from the aspect of agriculture in Indonesia, were raised and matured during the New Order era and the green revolution program was running in Indonesia. The two 
generations are mostly farmers who are the main actors in rural agricultural development in Indonesia today, and most of them are old, with an age range of 70-80 years old.

Generally, these farmers own farmland themself and cultivate it and part of them becomes farm labourers only. On the other hand, the millennial generation as a generation born by Generation X and baby boomers generally do not have agricultural land. Some of the phenomena currently occurring in agriculture in rural areas are the young generation of farmers' children, working outside the agricultural sector and leaving their villages, however, in the last decade, the millennial generation has high enthusiasm for doing business in agriculture in their villages [22]. Some of them continue to farm their parents by applying several agricultural technology innovations that were have not done by their parents before, such as intensification of cultivation of various vegetable crops with organic farming. This young millennial generation does different things from their parents in farming. They feel that the economic benefits of the rice farming that their parents have been done are less profitable, so they are more interested in vegetable farming.

Some of the phenomena that occur in urban areas that are trending and carried out by the current millennial generation in Indonesia are urban farming, vertical garden, and hydroponics. This phenomenon occurs due to the increasing market demand of urban communities for horticultural commodities. Commodity markets in these urban areas have specific and functional for specific needs, such as organic vegetables, exotic fruits, or black rice. Agricultural business in urban areas is generally carried out inland yards with a limited area. The agricultural business carried out by the millennial generation in urban areas has been widely supported by Information Technology which is generally familiar and skilled by them. The utilization of Information Technology, particularly the internet, generally uses applications installed on cell phones. Some of these applications include agricultural technology in the downstream to upstream aspects, such as applications for access to the availability of quality vegetable seeds or seeds, vegetable cultivation innovations, innovation in controlling and eradicating pests and plant diseases, and marketing applications for vegetable products. Most of these online applications are free to download and use.

The millennial generation has advantages compared to previous generations, which are generally familiar with and mastering digital technology, so this condition provides a high potential for utilizing this generation. Another condition that is relevant today in the context of the relationship with human resource development in Indonesia is the phenomenon of the demographic dividend that occurs in Indonesia. This situation makes the millennial generation the main subject or actor of the demographic bonus so that the millennial generation has a very important role as a driver of Indonesia's development, including in the agricultural sector.

Some ideal and favourable conditions that occur in designing and implementing for current and future Indonesian agricultural development, namely: 1) The condition of the demographic dividend which is filled with a productive workforce, 2) The subject of the demographic is dominating by the generation of millennials, 3) The growth of Information Technology in Indonesia is rapid, 4) Millennial generation is digitally native, 5) There is a trend of a millennial generation working in agriculture, both in urban and rural areas.

The condition of internet access for the Indonesian people is good, by looking at several aspects of the level of internet access (Table 1). Some of the current potentials in developing agriculture in rural areas in Indonesia are all rural areas in Indonesia, most of them have strong cellular signals, high ownership of each family in rural areas and most of the devices used to access the internet are through cell phones. These conditions indicate that agricultural development in rural areas has a high potential for success with the Information Technology utilization approach. 
Tabel 1. Profiles of Internet Access for Rural People in Indonesia In 2019

\begin{tabular}{|l|r|r|}
\hline \multicolumn{1}{|c|}{ Category } & \multicolumn{2}{|c|}{ Description } \\
\cline { 2 - 3 } & \multicolumn{1}{|c|}{ Quantity } & Per cent \\
\hline 1. Strength of Cellular Telephone Signals in rural areas ${ }^{*}$ : & & \\
\hline a. Strong Signal (village units) & 58,194 & 69.33 \\
\hline b. Weak Signal (village units) & 19,771 & 23.56 \\
\hline c. There is no signal (village units) & 5,972 & 7.11 \\
\hline 2. Households that have cell phones in rural areas ${ }^{*}$ ) & & 88.63 \\
\hline $\begin{array}{l}\text { 3. Media used in accessing internet in rural areas, } \\
\text { through }{ }^{*} \text { : }\end{array}$ & & \\
\hline a. Desktop/ PC (household units) & $3,757,928$ & 5.47 \\
\hline b. Laptop (household units) & $10,840,970$ & 15.78 \\
\hline c. Cellular phone (household units) & $66,605,329$ & 96.95 \\
\hline d. Other/ smart TV (household units) & 240,452 & 0.35 \\
\hline 4. The purpose of accessing information in rural areas $\left.{ }^{*}\right)$ & & \\
\hline a. Get information (household units) & $48,021,789$ & 69.90 \\
\hline b. Doing school or campus work (household units) & $17,766,001$ & 25.86 \\
\hline c. Make use of e-mail (household units) & $9,576,878$ & 13.94 \\
\hline d. Using social media (household units) & $59,907,010$ & 87.20 \\
\hline e. buying and selling online (household units) & $8,814,300$ & 12.83 \\
\hline f. Entertainment (household units) & $42,683,745$ & 62.13 \\
\hline g. Get financial facilities (household units) & $4,438,065$ & 6.46 \\
\hline h. Others (household units) & $2,232,773$ & 3.25 \\
\hline $\begin{array}{l}\text { 5. Telecommunications expenditure on total household } \\
\text { expenditure at }{ }^{* *} \text { : }\end{array}$ & & \\
\hline a. urban area (Rupiahs per household per month) & 185,000 & \\
\hline b. rural area (Rupiahs per household per month) & 106,000 & \\
\hline Source & & \\
\hline (1) & & \\
\hline
\end{tabular}

Source: $\left.{ }^{*}\right)[1]$
$\left.{ }^{* *}\right)[18]$

In addition to the potential, such as the high availability of internet access in all regions of Indonesia, another favourable and potential condition is the habit of internet users in rural areas, namely the high use of the internet to access information and access social media (Table 1), so that the media that needs to be used in developing the agricultural sector is through facilities such as the web and social media. The use of the internet for economic financing and buying and selling online is still low $(6.46 \%$ and $12.83 \%)$. This condition is a high opportunity for entrepreneurs, especially the millennial generation who are interested in entrepreneurship in agriculture to develop their product markets that related to agriculture and rural communities through internet facilities.

Some of these situations and conditions play an important key role for the millennial generation in Indonesia. Some of the key roles of Indonesia's current millennial generation, namely; 1) being the main locomotive and driving group in agricultural development because it is the largest group of a productive workforce now, 2) determining the new pattern of Indonesian agricultural development in the digital era, because it is the age group that masters Information Technology, 3) Becomes a driving force for rural development because most of the agricultural land is located in rural areas. One example of stimulating millennial youth to do business in the agricultural sector is by providing incentives, such as [23] said that it is time for the Indonesian government to start providing special incentives to the younger generation to encourage them to do business in the agricultural sector. This effort must be synergized with real government programs. 
The millennial generation group, according to [24] can be divided into several subgroups that have their character, namely; the adventure, the visionary, the leader, the conservative, the artist, the socializer, the collaborator. Each sub-group of the millennial generation has a different character when viewed from the aspects of values and traditions, career paths and workplace habits, media consumption, and internet and online behaviours. Agricultural development in Indonesia currently has the potential to be filled and utilized by millennial generations with these distinctive characters.

Several characters of the millennial generation that are suitable and following the needs of the current era, especially the current conditions of agricultural development in Indonesia, namely; 1) can survive and develop themselves from minimum conditions, such as subsistence agricultural conditions, 2) dare to try something new, such as starting entrepreneurship with support for digitization in agriculture, 3) able to establish good communication and collaboration with other people and in the team, such as working with elderly farmers and peer millennial generations, 4) having a tough, resilient, honest nature in starting and developing their business.

There is a suitable between some of these characters and the characters which said by [24], so there are several sub-groups of the millennial generation which suitable for developing agriculture now, firstly; a sub-group of "adventures" whose characteristics can influence other people so they can join with "the adventurers". They seek new challenges and experiences. They are more suitable to be entrepreneurs and The internet an adventurers' major source of productivity. Secondly, the sub-group of The visionary; create innovations to achieve long-term goals. They are innovators. They use the internet to discover new trends and insights. Some of the characteristics possessed by the adventures and the visionary are strong characteristics needed in facing and developing today's challenging agricultural sector. The visionary has character inspiring, charismatic, expressive, and driven. Visionaries tend to be over-achieving employees with an unquenchable thirst for knowledge and make great entrepreneurs. Adventurers are statistically more suitable to be entrepreneurs compared to other types of millennials, where $18 \%$ of them identified themselves as entrepreneurs, from micro to businessman [22].

In the context of developing human resource capacity, the Indonesian government has the responsibility to carry out the development of human resources, including in the agricultural sector. Act of Republic Indonesia Number 12 of 1992 About Plant Cultivation System [25] Article 56 and Act of Republic of Indonesia Number 22 of 2019 About Sustainable Agricultural Cultivation System [26] Article 91 and Article 92, which states that the Government has a role to carry out guidance in the agricultural sector through several means, activities, or channels.

The Indonesian government, both at the central and regional, has a role and responsibility in implementing these regulations. The implementation of these regulations can be carried out with several government development programs in the agricultural sector. Some of these government programs can be implemented directly to agriculture technical or through indirectly pattern with education and training at college or tertiary institutions. Some of these programs can be carried out through the educational process in higher education in ways such as field practice or Community Development Participation in villages, with the topic of the use of Information Technology, especially the use of cell phones to support the farming system process from upstream to downstream.

Another pattern can be implemented by the government with a social engineering pattern through several government programs. This program can be carried out through entrepreneurship education in rural agriculture based on the internet, an intensive program for village assistants by utilizing village funds, based on Information Technology. Another program is the financing of capital loans for millennial entrepreneurs to develop Information Technology-based farming business, through a loan scheme from the Bank. 


\section{Conclusion}

The millennial generation in Indonesia is the largest productive age group compared to other age groups now. This condition is a phenomenon of the demographic dividend in Indonesia. This millennial generation has advantages over other generations today, namely that this generation dominates the digital world that is currently developing rapidly in Indonesia. On the other hand, the internet access of the Indonesian people, especially the millennial generation in Indonesia is high today, so that the millennial generation in Indonesia has an important role in agricultural development in today's digital era in Indonesia.

The key roles of Indonesia's current millennial generation, namely; become the main locomotive and driving force in agricultural development, and become a determinant of the new pattern of Indonesian agricultural development in the digital era, because it is the most productive age group and the most masters of Information Technology. Another important role is to drive the development of rural areas because most agricultural land in Indonesia is located in rural areas.

Strategies in maximizing the role of the Indonesian millennial generation in agriculture can be carried out with the education process in higher education with an emphasis on the introduction and use of Information Technology for its application in the agricultural sector. Another strategy can be implemented by the government with a social engineering pattern through several government programs in the entrepreneurial aspect of rural agriculture based on the internet. Another strategy can be in the form of intensive programs for the millennial generation as village activists by utilizing village funds or bank loan schemes in developing internet-based agriculture.

\section{References}

1. Statistic Indonesia, Statistik Indonesia 2020 Statistical Yearbook of Indonesia 2020 (2020).

2. N. Rusono, A. Sunari, A. Candradijaya, I. Martino, and T. Tejaningsih, Analisis Nilai Tukar Petani (NTP) Sebagai Bahan Penyusunan RPJMN Tahun 2015-2019 (2013).

3. P. Simatupang, IAARD Press 269 (2018).

4. O. Oluseye M. and O. Oluwasanjo J., Sci. J. Agric. Res. Manag. 2012, (2012).

5. K. T. Sibhatu and M. Qaim, PLoS One 12, 1 (2017).

6. C. Miruka and M. Kabegambire, Ghana J. Dev. Stud. 11, 67 (2015).

7. Syahyuti, Forum Penelit. Agro Ekon. 15 (2013).

8. P. N. Nena, Factors Affecting Subsistence Farmers 'Adoption of Sustainable Land Management Practices in Oshikoto Region , Namibia (Iceland, 2015).

9. S. Davidova, L. Fredriksson, M. Gorton, P. Mishev, and D. Petrovici, Environ. Plan. C Gov. Policy 30, 209 (2012).

10. P. Kostov and J. Lingard, J. Agric. Econ. 55, 565 (2004).

11. S. Onakuse, J. Agric. Food Syst. Community Dev. 3, 61 (2012).

12. J. Mariyono, Asia Pacific Policy Stud. 6, 246 (2019).

13. S. H. Susilowati, Forum Penelit. Agroecon. 34, 35 (2016).

14. W. R. Jati, Populasi 23, 1 (2015).

15. P. Taylor, The Next America, First (Public Affairs, New York, 2014).

16. R. Zemke, C. Raines, and B. Filipczak, Generations at Work, 10th ed. (Amacom, New 
York, 2000).

17. J. Bejtkovsky, J. Compet. 8, 105 (2016).

18. Indonesia Survey Center, Laporan Survei Internet APJII 2020 (Jakarta, 2020).

19. S. W. N. Eddy and J. M. Johnson, Burke 01, 121 (2015).

20. O. S. Karashchuk, E. A. Mayorova, A. F. Nikishin, and O. V. Kornilova, SAGE Open 10, (2020).

21. N. Howe and W. Strauss, Harv. Bus. Rev. 85, 41 (2007).

22. D. Gandasari, D. Dwidienawati, S. Suwardi, and R. Permatasari, 29, 7697 (2020).

23. S. H. Susilowati, Forum Penelit. Agro Ekon. 34, 103 (2016).

24. W. and N. R. Utomo, Indonesia Millennial Report (DN Research Institute, Jakarta, 2020).

25. Nation secretary of Republic Indonesia, Act of Republic Indonesia Number 12 of 1992 About Plant Cultivation System (1992), pp. 1-62.

26. Nation secretary of Republic Indonesia, Act of Republic of Indonesia Number 22 of 2019 About Sustainable Agricultural Cultivation System (2019), pp. 19501-19571. 